\title{
Generation of high-intensity ultra-short optical pulses: 2018 Nobel Prize Winners in Physics Gerard Mourou and Donna Strickland
}

\author{
Vyacheslav M. Tyutyunnik $\square$ \\ Tambov State Technical University, 106, Sovetskaya St., Tambov 392000, Russian Federation, \\ International Nobel Information Centre (INIC), 30-6, Pervomaiskaya Sq., Tambov 392002, Russian Federation \\ $\triangle$ vmtyutyunnik@gmail.com
}

\begin{abstract}
In the early 1980s, French physicist G. Mourou and his Canadian collaborator D. Strickland solved the problem of power drop by dispersing in time and space the processes of amplification and compression: a method of obtaining super-powerful chirped laser pulses ( $C P A$ - chirped pulse amplification). The paper presents brief biographical references to Mourou and Strickland. The 2018 Nobel Prize in Physics was awarded "for groundbreaking inventions in the field of laser physics": Artur Isidorovich Ashkin (Ashkinazi, born 02.09.1922, USA), half of the prize "for the optical tweezers and their application to biological systems"; Gerard Albert Mourou and Donna Theo Strickland (became the third woman to be awarded the Nobel Prize in Physics) (quarterly premium) "for their method of generating high-intensity, ultra-short optical pulses". Since that time all lasers have been built on a new principle: after the amplifiers place a compressor from diffraction bars. Instead of simply amplifying the pulse, it is first spread out on spectral components spread over time, then they are amplified separately, then again assembled into a single pulse. At each point in time, only a fraction of the pulse is amplified, not the entire pulse, allowing for a much higher peak intensity of laser light flow.
\end{abstract}

Keywords: laser physics; high-intensity ultra-short optical pulses; chirped pulse amplification; generation; 2018 Nobel Prize winners in Physics Gerard Mourou and Donna Strickland.

For citation: Tyutyunnik VM. Generation of high-intensity ultra-short optical pulses: 2018 Nobel Prize Winners in Physics Gerard Mourou and Donna Strickland. Journal of Advanced Materials and Technologies. 2021;6(2):87-90. DOI: 10.17277/jamt.2021.02.pp.087-090

\section{Генерация высокоинтенсивных ультракоротких оптических импульсов: лауреаты Нобелевской премии по физике 2018 года Жерар Муру и Донна Стрикленд}

\author{
В. М. Тютюнник $\bowtie$ \\ Тамбовский государственный технический университет, \\ ул. Советская, 106, Тамбов 392000, Российская Федерация, \\ Международный Информачиионый Нобелевский Центр (МИНЦ), \\ Первомайская площуадь, 30-6, Тамбов 392002, Российская Федерация \\ $\triangle$ vmtyutyunnik@gmail.com
}

\begin{abstract}
Аннотация: В начале 1980-х годов французский физик Ж. Муру вместе со своей канадской сотрудницей Д. Стрикленд решили проблему падения мощности путем разнесения во времени и пространстве процессов усиления и сжатия: метод получения сверхмощных чирпированных лазерных импульсов (CPA-chirped pulse amplification). Приведены краткие биографические сведения Муру и Стрикленд. Нобелевская премия по физике за 2018 г. присуждена «за новаторские изобретения в области лазерной физики»: Артуру Исидоровичу Ашкину (Ашкинази, родился 02.09.1922, США) - половина премии «за оптические пинцеты и их применение в биологических системах»; Жерару Альберу Муру и Донне Тео Стрикленд (третья женщина, удостоенная Нобелевской премии по физике) (по четверти премии) «за метод генерации высокоинтенсивных ультракоротких
\end{abstract}


оптических импульсов». Теперь все лазеры построены на новом принципе: после усилителей размещают компрессор из дифракционных решеток. Вместо простого усиления импульс сначала раскладывается на спектральные компоненты, разнесенные во времени, затем они усиливаются по отдельности, потом снова собираются в единый импульс. В каждый момент времени усиливается только часть импульса, а не весь импульс целиком, что позволяет достичь гораздо более высокой пиковой интенсивности лазерного светового потока.

Ключевые слова: лазерная физика; высокоинтенсивные ультракороткие оптические импульсы; сверхмощные лазерные импульсы; генерация; лауреаты Нобелевской премии по физике 2018 года Жерар Муру и Донна Стрикленд.

Для цитирования:. Tyutyunnik VM. Generation of high-intensity ultra-short optical pulses: 2018 Nobel Prize Winners in Physics Gerard Mourou and Donna Strickland. Journal of Advanced Materials and Technologies. 2021;6(2):87-90. DOI: 10.17277/jamt.2021.02.pp.087-090

Since 1964 when the classic works of AM Prokhorov, NG Basov and ChKh Townes were awarded the Nobel Prize in Physics, laser physics has gradually become one of the most prominent directions of modern physical science [1-3]. Its main task is to increase the power of the particle beam using shorter pulses and to compress the beam itself. For a long time for this, physicists first stretched the pulse in time, and then squeezed it. However, as a result of these operations, power dropped.

In the early 1980s, French physicist Gerard Mourou, together with his Canadian colleague Donna Strickland, solved the problem of power drop by separating amplification and compression processes in time and space. Mourou's and Strickland's invention is called the method of chirped pulse amplification (CPA).

Gerard Albert Mourou was born on June 22, 1944 in Albertville (France). In 1967 he graduated from the Physics Department of the University of Grenoble, and then he worked at the Ecole Polytechnique. He worked at the University of Laval in Canada, at the University of California in San Diego (USA), and then he set up a research team on ultrafast processes in Paris. In 1977 he moved to the United States - first to the University of Rochester (New York), and in 1988 to the position of professor at the University of Michigan, where he founded and for a long time headed the Center for Ultrafast Optics. In 2004, Mourou returned to France as Director of the Applied Optics Laboratory at the National Graduate School of Advanced Technologies. In 2008 he was elected a foreign member of the Russian Academy of Sciences [4]. In 2010, under the first megagrant program (about 300 scientific laboratories have been created in Russian universities and scientific organizations within ten years), Mourou was invited to Nizhny Novgorod State University, to the laboratory of the future President of the Russian Academy of Sciences AM Sergeev to study the clearing of space from debris using lasers and reducing the lifetime of nuclear waste. Mourou took part in the creation and development of the Extreme Light Sources and Applications (ELSA) laboratory, which had had three powerful experimental laser systems - multipetawatt, attosecond and terahertz by 2016. In 2020, he once again flew to Russia and participated in the V AllRussian Research Forum "Science of the Future Science of the Young". In an interview with TASS, he noted: "The development of modern world science is impossible without the participation of Russia. Russia, without any doubt, is one of the most important participants in world science; there can be no doubt about that. Science has no boundaries, and the work of the world's leading scientists to overcome the problem of the COVID-19 pandemic has once again confirmed this" (translated by me - V.T.)

The main directions of Mourou's research are laser physics and nonlinear optics. In 1985, he developed a new technology for producing ultrahigh-power laser pulses - amplification of chirped pulses, which is the main one for obtaining femtosecond pulses [5]. To date, he coordinates the Pan-European Extreme Light Infrastructure project to create an exawatt laser system. Mourou is a member of the US National Academy of Engineering (2002), the US Optical Society, the American Physical Society, and the Institute of Electrical and Electronics Engineers.

Donna Theo Strickland was born on May 27, 1959 in Guelph (Ontario, Canada). Having graduated from McMaster University in Hamilton in 1981 with a degree in engineering physics, in 1989, she received her Ph.D. in physics from the University of Rochester, where she was supervised by Professor Mourou. She studied chirped pulse amplification followed by their compression, which made it possible to amplify ultrashort pulses to colossal levels. From 1988 to 1991 she was a Research Fellow at the National Research Council of Canada. She currently works at the University of Waterloo, where she leads research on high-intensity laser systems for nonlinear optics. She is a Fellow of the Royal Society of London (2020), Foreign Fellow of the US National Academy of Sciences (2020), 


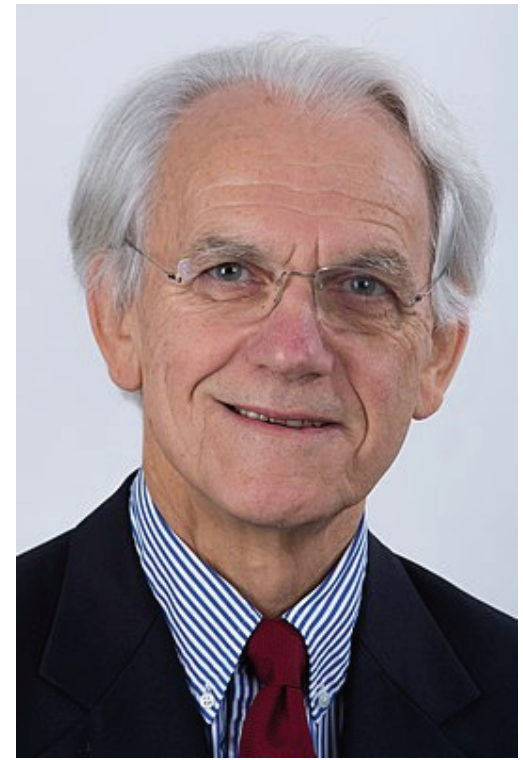

Gerard Mourou

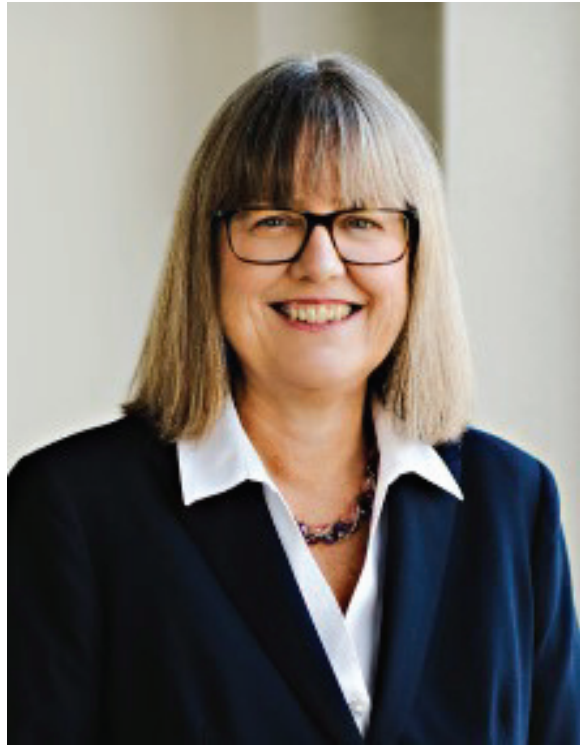

Donna Theo Strickland

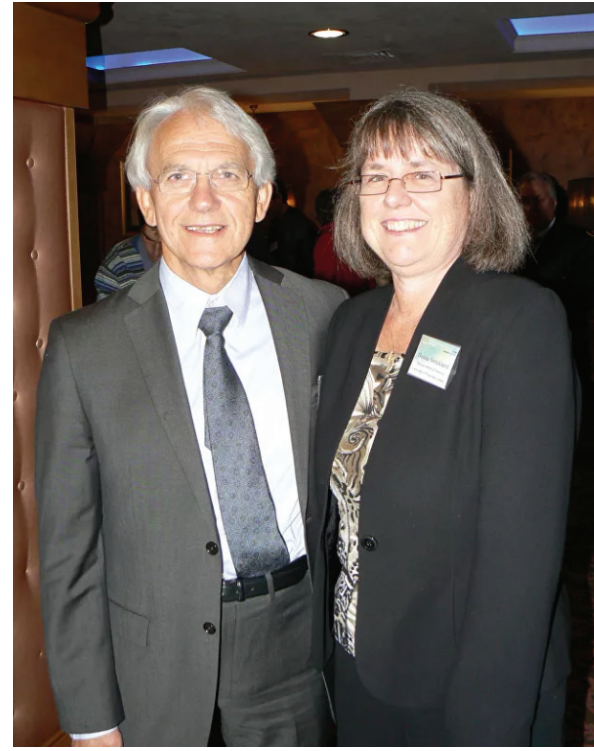

Mourou and Strickland at a conference on 50th anniversary of nonlinear optics (Suzdal, 2011)
Vice President (2011), then President (2013) of the Optical Society of Canada.

The Nobel Prize in Physics for 2018 was awarded "for innovative inventions in the field of laser physics": Artur Isidorovich Ashkin (Ashkinazi, born 2 September 1922, USA) - half of the prize "for optical tweezers and their application in biological systems"; Gerard Albert Mourou and Donna Theo Strickland (quarter prize each) for the method of generating high-intensity ultrashort optical pulses. Now all lasers are built on this principle: a compressor made of diffraction gratings is placed after the amplifiers (Fig. 1). Instead of simple amplification, the pulse is first decomposed into spectral components separated in time, and then they are amplified separately, and then again collected into a single pulse.

At each moment in time, only a part of the pulse is amplified, and not the entire pulse, which makes it possible to achieve a much higher peak intensity of the laser light flux. This technology has a lot of practical applications and excellent prospects (Fig. 2).

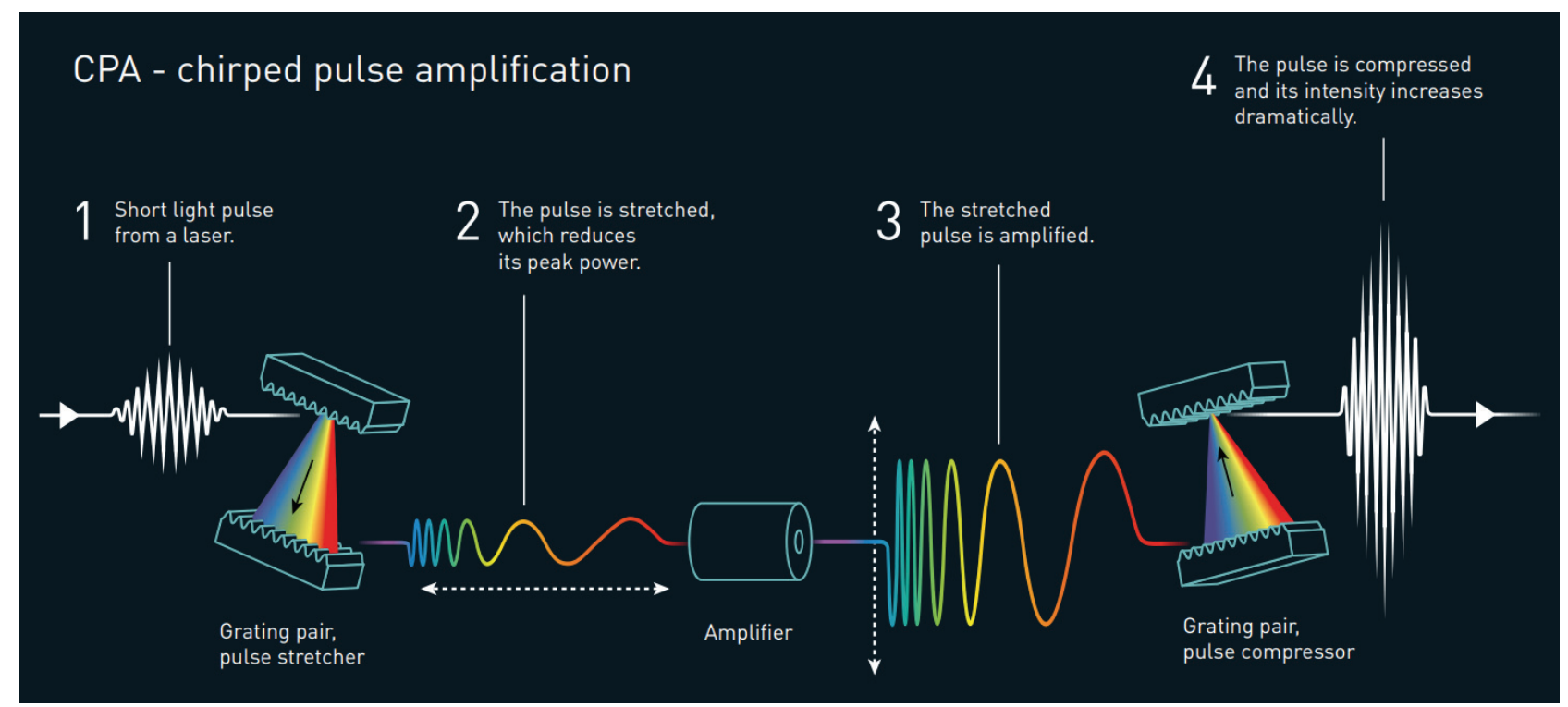

Fig. 1. The main elements of technology CPA [6] 


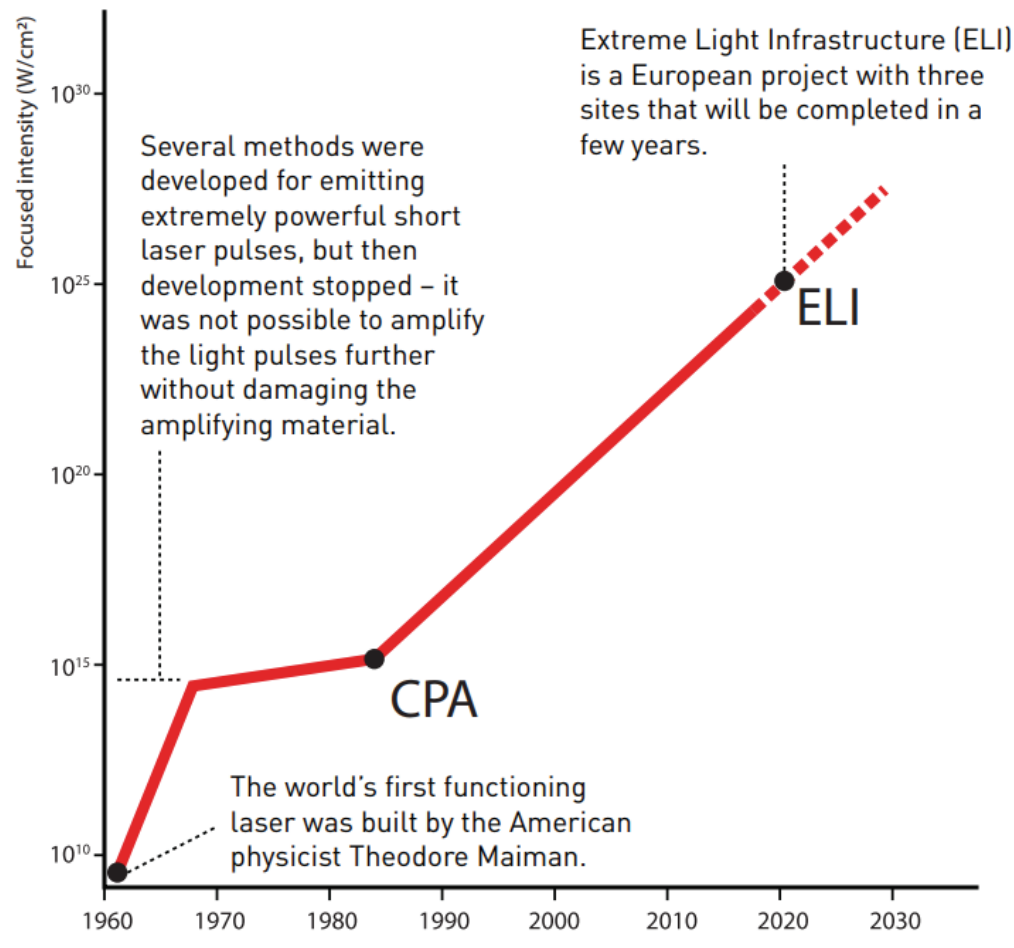

Fig. 2. Development of the highest intensity laser pulse technology [6]

This study did not receive external funding.

There is no conflict of interest.

\section{References}

1. Tyutyunnik VM. Trends and peculiarities of the development of modern science: nominees and nominators for the Nobel Prizes in Physics and Chemistry. Formirovanie professionala $v$ usloviyakh regiona $=$ Formation of a professional in the region condition: Materials XXI Intern. Sci. Conf., Tambov, March 22-23, 2020. Tambov, Moscow, St. Petersburg, Baku, Vienna, Hamburg, Stockholm, Bouake, Varna, Tashkent: INIC Publ. House "Nobelistics", 2020, pp. 116-163. (In Russ.)

2. Tyutyunnik VM. Nominated for the Nobel Prize in Physics in 1911-1950. Inzhenernaya fiszika $=$ Engineering physics. 2021;2:10-33. DOI:10.25791/infizik.2.2021.1189 (In Russ.)
3. Tyutyunnik VM. Graphene breakthrough into future technology: the 2010 Nobel Prize in Physics Laureate Sir Konstantin Sergeevich Novoselov. Journal of Advanced Materials and Technologies. 2021;6(1):6-9. DOI:10.17277/jamt.2021.01.pp.006-009

4. Tyutyunnik VM. Nobel laureates, domestic and foreign members and winners of awards of the Russian Academy of Sciences. Istoriya nauki i tekhniki $=$ History of science and technology. 2020;9:3-26. DOI:10.25791/intstg.09.2020.1210 (In Russ.)

5. Strickland D, Mourou G. Compression of amplified chirped optical pulses. Optics Communications. 1985;56(3):219-221. DOI:10.1016/0030-4018(85)90120-8

6. Scientific Background on the Nobel Prize in Physics 2018. Available from: https://www.nobelprize.org/ uploads/2018/10/advanced-physicsprize2018.pdf

[Accessed 18 June 2018]

\section{Информация об авторах / Information about the authors}

Тютюнник Вячеслав Михайлович, доктор технических наук, профессор, Тамбовский государственный технический университет; генеральный директор, Международный Информационный Нобелевский Центр, Тамбов, Российская Федерация; ORCID 00000002-2099-5730; e-mail: vmtyutyunnik@gmail.com
Vyacheslav M. Tyutyunnik, D. Sc. (Engineering), Professor, Tambov State Technical University; Director General, International Nobel Information Centre, Tambov, Russian Federation; ORCID 0000-0002-20995730; e-mail: vmtyutyunnik@gmail.com

Received 19 April 2021; Accepted 19 May 2021; Published 02 Jule 2021

Copyright: (C) Tyutyunnik VM, 2021. This article is an open access article distributed under the terms and conditions of the Creative Commons Attribution (CC BY) license (https://creativecommons.org/licenses/by/4.0/). 